\title{
Searching for Evidence-Based Medicine in the Literature Part 3: Assessment
}

\section{Keywords:}

Evidence-based medicine;

Health care quality, access, and evaluation; Computer-assisted instruction; Internet
Reprint Requests:

Barbara A. Bartkowiak, MLIS, MST

George E. Magnin Medical Library

Marshfield Clinic

1000 N. Oak Avenue

Marshfield, WI 54449

Tel: 7 I 5-389-4285

Fax: 7I5-389-5366

Email: bartkowiak.barbara@mcrf.mfldclin.edu
Received: January 20, 2005

Accepted: February 14, 2005
Barbara A. Bartkowiak, MLIS, MST

A fter composing a pointed question for an evidence-based medicine (EBM) search and then selecting appropriate resources for its execution, the final step requires an assessment of the information gleaned: what is substantive material and what is not?

Unless one is especially adept at statistics and/or EBM methodology, it may appear that one study is as good as another and, consequently, the researcher can feel muddled by the retrieval. Critical appraisal in EBM generally centers around three questions: 1) is it valid?, 2) what are the results?, and 3) is it applicable to the patient? One is trying to determine if the study's evidence demonstrates enough rigor within its methodology to impact the course of a particular patient's care. It may be tempting to view critical appraisal as an invitation to negate or castigate clinical study efforts but, in a real world, no study can be perfectly designed or executed. The main purpose of critical appraisal is to "assess not whether a paper is 'rubbish', but whether there is so much potential bias that the results are no longer valid". ${ }^{1}$ While the determination of validity is not easy and relevance to patient care is sometimes obscured, two resources that can assist in the evaluation of good, better, and best EBM information can be accessed electronically.

At the Critical Appraisal Skills Programme (CASP) section of the United Kingdom's National Health Service web site (http://www.phru.nhs.uk/casp/appraisa.htm), a wealth of resources provides a rich repository. Especially useful are forms described as critical appraisal tools for various types of articles including systematic reviews, randomized controlled trials, cohort studies, case control studies, diagnostic test studies and economic evaluation studies. Each form consists of ten questions about each specific type of article, which are supplemented with prompts that assist in the assessment of each question topic. The questions derive from a notable series titled "Users' Guides to the Medical Literature," which appeared in the Journal of the American Medical Association (JAMA) from 1993 through 20002-34 and, as such, constitute a solid approach to evidence-based assessment. In terms of function, the forms demonstrate attention to clarity in font size, strong contrast in design, and an efficient screening section in each article type that determines whether one should proceed through all ten questions or stop. While the roomy, clear forms may be used only for an individual's personal use, the web site also provides a method to obtaining copyright permission if one wanted to use them in a group practice or other setting. 
Another useful web site that offers a step-by-step approach to critical appraisal can be found at the Centre for Evidence-Based Medicine in Oxford, England (http://www.cebm.net/ critical_appraisal.asp). Worksheets provided for the assessment of articles relating to diagnosis, harm, etiology, therapy and systematic reviews of therapy can be accessed separately or downloaded as a group. Each type of article evaluation requires a different approach to determination of validity; critical questions and demonstrations of specific calculations are customized for each worksheet set. The addition of statistics can be daunting, but the authors supply understandable sample calculations and then provide a practice section for the user's skill development. The last section of the form consists of patient-related questions to focus the results of the inquiry and, as such, cinches the usefulness of the worksheets. The aim of the worksheet exercise is to determine the article's relevance to an individual patient's care, and these worksheets provide an effective and cogent methodology to do so.

While there are many evidence-based medicine resources, it is more difficult to find those with an easy and efficient approach to a rather complex area. Without compromising quality or exhausting time, one can find respectable EBM web resources to compose a suitable question, execute a viable literature search, and then assess the trustworthiness of the materials gleaned. Certainly more time and resources are needed for extended systematic assessments, but the busy practitioner can use evidence-based medicine in daily practice and still feel comfortable about the results for specific patient care.

\section{References}

1. Dawes M, Davies P, Gray A, Mant J, Seers K, Snowball R, Kitson A. Evidence-based practice: a primer for health care professionals. Edinburgh: Churchill Livingstone; 1999. 48.

2. Oxman AD, Sackett DL, Guyatt GH. Users' guides to the medical literature. I. How to get started. The Evidence-Based Medicine Working Group. JAMA 1993;270:2093-2095.

3. Guyatt GH, Rennie D. Users' guides to the medical literature. JAMA 1993;270:2096-2097.

4. Guyatt GH, Sackett DL, Cook DJ. Users' guides to the medical literature. II. How to use an article about therapy or prevention. A. Are the results of the study valid? Evidence-Based Medicine Working Group. JAMA 1993;270:2598-2601.

5. Guyatt GH, Sackett DL, Cook DJ. Users' guides to the medical literature. II. How to use an article about therapy or prevention. B. What were the results and will they help me in caring for my patients? Evidence-Based Medicine Working Group. JAMA 1994;271:59-63.

6. Jaeschke R, Guyatt G, Sackett DL. Users' guides to the medical literature. III. How to use an article about a diagnostic test. A. Are the results of the study valid? Evidence-Based Medicine Working Group. JAMA 1994;271:389-391.

7. Jaeschke R, Guyatt G, Sackett DL. Users' guides to the medical literature. III. How to use an article about a diagnostic test. B. What are the results and will they help me in caring for my patients? Evidence-Based Medicine Working Group. JAMA 1994;271:703-707.

8. Levine M, Walter S, Lee H, Haines T, Holbrook A, Moyer V. Users' guides to the medical literature. IV. How to use an article about harm. Evidence-Based Medicine Working Group. JAMA 1994;271:1615-1619.
9. Laupacis A, Wells G, Richardson WS, Tugwell P. Users' guides to the medical literature. V. How to use an article about prognosis. Evidence-Based Medicine Working Group. JAMA 1994;272:234-237.

10. Oxman AD, Cook DJ, Guyatt GH. Users' guides to the medical literature. VI. How to use an overview. Evidence-Based Medicine Working Group. JAMA 1995;274:217-218.

11. Richardson WS, Detsky AS. Users' guides to the medical literature. VII. How to use a clinical decision analysis. A. Are the results of the study valid? Evidence-Based Medicine Working Group. JAMA 1995;273:1292-1295.

12. Richardson WS, Detsky AS. Users' guides to the medical literature. VII. How to use a clinical decision analysis. B. What are the results and will they help me in caring for my patients? Evidence-Based Medicine Working Group. JAMA 1995;273:1610-1613.

13. Hayward RS, Wilson MC, Tunis SR, Bass EB, Guyatt G. Users' guides to the medical literature. VIII. How to use clinical practice guidelines. A. Are the recommendations valid? Evidence-Based Medicine Working Group. JAMA 1995;274:570-574.

14. Hayward RS, Wilson MC, Tunis SR, Bass EB, Guyatt G. Users' guides to the medical literature. VIII. How to use clinical practice guidelines. B. What are the recommendations and will they help you in caring for your patients? Evidence-Based Medicine Working Group. JAMA 1995;274:1630-1632.

15. Guyatt GH, Sackett DL, Sinclair JC, Hayward R, Cook DJ, Cook RJ. Users' guides to the medical literature. IX. A method for grading health care recommendations. Evidence-Based Medicine Working Group. JAMA 1995;275:1232.

16. Naylor CD, Guyatt GH. Users' guides to the medical literature. X. How to use an article reporting variations in the outcomes of health services. The Evidence-Based Medicine Working Group. JAMA 1996;275:554-558.

17. Naylor CD, Guyatt GH. Users' guides to the medical literature. XI. How to use an article about a clinical utilization review. Evidence-Based Medicine Working Group. JAMA 1996;275:1435-1439.

18. Guyatt GH, Naylor CD, Juniper E, Heyland DK, Jaeschke R, Cook DJ. Users' guides to the medical literature. XII. How to use articles about health-related quality of life. Evidence-Based Medicine Working Group. JAMA 1997;277:1232-1237.

19. Drummond MF, Richardson WS, O'Brien BJ, Levine M, Heyland D. Users' guides to the medical literature. XIII. How to use an article on economic analysis of clinical practice. A. Are the results of the study valid? Evidence-Based Medicine Working Group. JAMA 1997;277:1552-1557.

20. O'Brien BJ, Heyland D, Richardson WS, Levine M, Drummond MF. Users' guides to the medical literature. XIII. How to use an article on economic analysis of clinical practice. B. What are the results and will they help me in caring for my patients? Evidence-Based Medicine Working Group. JAMA 1997;277:1802-1806.

21. Dans AL, Dans LF, Guyatt GH, Richardson S. Users' guides to the medical literature: XIV. How to decide on the applicability of clinical trial results to your patient. Evidence-Based Medicine Working Group. JAMA 1998;279:545-549.

22. Richardson WS, Wilson MC, Guyatt GH, Cook DJ, Nishikawa J. Users' guides to the medical literature: XV. How to use an article about disease probability for differential diagnosis. Evidence-Based Medicine Working Group. JAMA 1999;281:1214-1219.

23. Guyatt GH, Sinclair J, Cook DJ, Glasziou P. Users' guides to the medical literature: XVI. How to use a treatment recommendation. Evidence-Based Medicine Working Group and the Cochrane Applicability Methods Working Group. JAMA 1999;281:1836-1843. 
24. Barratt A, Irwig L, Glasziou P, Cumming RG, Raffle A, Hicks N, Gray JA, Guyatt GH. Users' guides to the medical literature: XVII. How to use guidelines and recommendations about screening. Evidence-Based Medicine Working Group. JAMA 1999;281:2029-2034.

25. Randolph AG, Haynes RB, Wyatt JC, Cook DJ, Guyatt GH. Users' guides to the medical literature: XVIII. How to use an article evaluating the clinical impact of a computer-based clinical decision support system. JAMA 1999;282:67-74.

26. Bucher HC, Guyatt GH, Cook DJ, Holbrook A, McAlister FA. Users' guides to the medical literature: XIX. Applying clincal trial results. A. How to use an article measuring the effect of an intervention on surrogate end points. Evidence-Based Medicine Working Group. JAMA 1999;282:771-778.

27. McAlister FA, Laupacis A, Wells GA, Sackett DL. Users' guides to the medical literature: XIX. Applying clinical trial results. B. Guidelines for determining whether a drug is exerting (more than) a class effect. JAMA 2000;283:1139-1140.

28. Hunt DL, Jaeschke R, McKibbon KA. Users' guides to the medical literature: XXI. Using electronic health information resources in evidence-based practice. Evidence-Based Medicine Working Group. JAMA 2000;283:1875-1879.

29. McAlister FA, Straus SE, Guyatt GH, Haynes RB. Users' guides to the medical literature: XX. Integrating research evidence with the care of the individual patient. Evidence-Based Medicine Working Group. JAMA 2000;283:2829-2836.

30. McGinn TG, Guyatt GH, Wyer PC, Naylor CD, Stiell IG, Richardson WS. Users' guides to the medical literature: XXII: how to use articles about clinical decision rules. Evidence-Based Medicine Working Group. JAMA 2000;284:79-84.

31. Giacomini MK, Cook DJ. Users' guides to the medical literature: XXIII. Qualitative research in health care. A. Are the results of the study valid? Evidence-Based Medicine Working Group. JAMA 2000;284:357-362.

32. Giacomini MK, Cook DJ. Users' guides to the medical literature: XXIII. Qualitative research in health care. B. What are the results and how do they help me care for my patients? Evidence-Based Medicine Working Group. JAMA 2000;284:478-482.

33. Richardson WS, Wilson MC, Williams JW Jr, Moyer VA, Naylor CD. Users' guides to the medical literature: XXIV. How to use an article on the clinical manifestations of disease. Evidence-Based Medicine Working Group. JAMA 2000;284:869-875.

34. Guyatt GH, Haynes RB, Jaeschke RZ, Cook DJ, Green L, Naylor $\mathrm{CD}$, Wilson MC, Richardson WS. Users' guides to the medical literature: XXV. Evidence-based medicine: principles for applying the Users' Guides to patient care. Evidence-Based Medicine Working Group. JAMA 2000;284:3127-3128.

\section{Author Affiliation}

Barbara A. Bartkowiak, MLIS, MST, George E. Magnin

Medical Library, Marshfield Clinic, 1000 N. Oak Avenue,

Marshfield, WI 54449. 